\title{
A Postscript for Maria
}

\author{
Marlene Kadar
}

\section{Un post-scriptum pour Maria}

En français, c'est possible d'écrire et en même temps de raconter et de narrer. En 1979, j'habitais dे Budapest et j'ai eu besoin de raconter une vieille histoire. Le conte, 'Postscriptum pour Maria, I,' présente Marie à vingt-six ans parmi des adolescentes à la communion solennelle cherchant à imiter la vièrge Marie immaculée pour fuireson corps maculéde sang, de 'putain,' comme disait son père. Maintenant, en 1989, $j$ 'ai besoin de narrer. J'ai abordéla narration pour Maria cette fois à travers un récit auto-réflexif et par le biais de la narratologie, pour produire 'Postscriptum pour Maria, II' qui a l'air d'un conte. Entre deux types de narration, entre l'épopée et le récit, se situent deux époques historiques, deux sexes et deux 'personnes' ('elle' et 'moi') différentes. 'Maria' se trouve quelque part dans, et entre, les deux moments, les deux textes.

\section{Woman Begun}

When Maria was sixteen, and had just got her period for the first time, her impassioned father had called her a whore. He had willingly misunderstood why she had been to the doctor. (Why was the bleedingmaking her faint?) Maria was 26 now, and somehow womanhood still felt dirty to her.

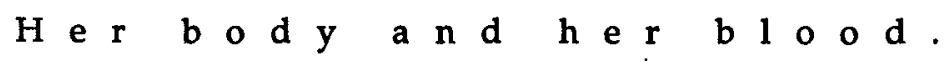

She would be like the virgin mother, and maybe it would go away. Although she didn't really believe what they told her about immaculate conception, it was the idea that mattered. The virgin became a mother, and she was the only woman that her father thought unsullied. Even Maria, when she saw pictures of the holy virgin, felt lit up 
inside. Was it her goodness that inspired her? There Mary was, in every pièta, without wrinkles and without a man. But she did have a child, and she did bring men (and women) to their knees.

Maria had thought that it was only when she had stopped being a child that her father's love for her had dwindled. He never got close to her any more. He rarely touched her. He thought many things were im p r o p e r. Unlike his real Canadian friends, he was too passionate. When he read the bible he would drink whiskey and weep about his own mother, and about feelings that were not mentioned in other circumstances. His distance was out of character.

\section{(Maria felt dirty without his touch.)}

Even though she was an adolescent, she went to church, hoping to be cleansed. She studied catechism for 6 months in preparation for her first holy communion with the lord jesus.

\section{lord jesus son of god mary's baby.}

She remembered the night she was blessed with great clarity. It was cold and very dark, a few days after New Year's. The chubby little monseigneur, himself a virgin they said, mumbled something at her in a very unholy voice, and she awkwardly opened her mouth to receive the fearful gift. He said

b o d y of c h r is t "

and Maria pretended with all the other little communicants that she was eating the body of christ. She was renamed Clarissa

(for the lord).

She remembered the bright lights hanging from the ceiling of the church in the shape of a crucifix. They beamed warm on her head. She remembered the long white line of veiled girls stretching across the nave of the church, the very threshold of Hymen's temple. This was, after all, a grand communion with their lord. The younger girls were excited. What was this bread and wine really going to do them? The 
fathers sat behind them, proud, expectant, waiting for the secret transformation. Daughters now somehow protected by having eaten the mysterious man's flesh

\section{t h e b o d y .}

Maria was the only adult in the queue. Perhaps she would beyoung and innocent forever now. Maybe she would never have to see man's penis, she thought, as the chubby little priest blessed her again.

Budapest, 14 February 1979

\section{II \\ Why Does She Narrate? \\ (She narrates because it feels good.)}

1) In Anglo-Latin narrare, narratio and narrator were used from the twelfth century specifically in law with reference to the statement of a claim or plea. (from the $O E D$ )

2) Give an account or history of. Only occasionally before c. 1750; stigmatized as Scottish by [Samuel] Richardson, [Samuel] Johnson, and [James] Beattie; cf. 'the abominable verb "narrate," which must absolutely be proscribed in all good writing' (Quarterly Review, 1813, July, 433). (from the $O E D$ )

3) Formed on past participle stem of Latin narrare (formed on gnarus knowing; cf. ignorare ignore). (from the $O E D$ )

She narrates because 'she' is not 'me.' And yet there is something that she remembers that has everything to do with the memory of me.

What I remember is more like a broken epic than a narrative. It is primitive, episodic, borders on history, and slips into myth and legend because the remembered does not have an ending. What I choose to tell (or remember?) comes out of this broken epic.

Unbroken epics are said to be lofty in style, and they are the songs of nations. They are warrior texts, always on the offensive, ready at all 
times for whatever the future of wars, of words, may bring. The unbroken epic is an offensive weapon in death-dealing negotiations about how nations will tell their stories (about themselves), how the law will state the client's claim or plea. The client is not the girl. The girl does not tell the story, but she is put in the story for the client.

The change from epic to narrative does not seem subversive, except that with the verb 'to narrate,' 'she,' too, was proscribed, 'an abominable verb,' a pronoun, not to be used in good writing. She didn't narrate because she was not a verb. She was not good writing, and then she met me and became undeniably lofty in style.

But she is not me. She is Maria, and she is narrated in the third person. She does not speak then, but she thinks about herself and her future words, her war. Her silence is her busy imagination.

Knowing her can only occur in the distance established between the narrator and Maria, and in the narrator's (dishonest) protection of truth. The narrator does not hate penises, but she knows I could. The narrator does not go to church, but she knows I might. The narrator does not (often) dreamabout the Virgin Mary, butshe knows I can. The narrator is a feminist, and she knows Maria is able. The narrative belongs to Maria. Or does the narrative belong to the narrator? Whose story is this?

If the author knew whose story it really was she would be me. And she would not continue (narrate) to break the epic into even smaller pieces (narrations) of remembered 'knowing' and 'ignoring.' Maria knows she is a hero who is becoming a woman. Sheis a person who can use verbs.

Toronto, 8 May 1989. 